\title{
Pengaruh Kondisi Keuangan, Audit Tenure, dan Ukuran KAP terhadap Opini Audit Going Concern pada Perusahaan Manufaktur yang Terdaftar di BEI Tahun 2012-2016
}

\author{
Maria Dini Yanuariska
}

Kantor Konsultan Pajak Benny Gunawan dan Rekan

\section{Aloysia Yanti Ardiati}

Universitas Atma Jaya Yogyakarta

Korespondensi penulis: yanti.ardiati@gmail.com

Article Info:

Received 27 June 2018

Accepted 30 June 2018

Available online 30 June 2018

Abstract: Going concern audit opinion is the survival of a company. A company that is considered unable to maintain its survival will receive going concern audit opinion. This opinion is bad news for users of financial statements (Astuti and Darsono, 2012). This research was conducted at manufacturing companies listed in Indonesia Stock Exchange from 2012 until 2016. Based on the criteria of research sample, it was obtained 400 research samples. The purpose of this research was to discover the effect of financial condition, audit tenure, and the size of public accountant office on going concern audit opinion. The results of this study indicated that the financial condition had a positive effect on going concern audit opinion, audit tenure had negative effect on going concern audit opinion, and the size of public accountant office had no effect on going concern audit opinion.

Keywords: Audit tenure, Financial condition, Going concern audit opinion, The size of Public Accountant Office.

\section{LATAR BELAKANG}

Pertumbuhan dan perkembangan dunia bisnis saat ini berkembang sangat pesat. Hal tersebut mengakibatkan persaingan antara pelaku bisnis yang satu dengan yang lain menjadi semakin ketat. Untuk mengetahui bagaimana keadaan perusahaan itu sendiri diperlukan laporan keuangan yang mencerminkan hasil dari kegiatan operasi perusahaan dan keberlangsungan suatu perusahaan. Laporan keuangan yang disajikan perusahaan sangat penting bagi manajemen dan pemilik perusahaan (Kasmir, 2017). Hal tersebut karena laporan keuangan menunjukkan apakah suatu perusahaan dapat mempertahankan kelangsungan hidupnya atau tidak. Menurut Setiawan (2006) dalam Fernando dan Hadiprajitno (2015), kelangsungan hidup perusahaan secara langsung dapat mempengaruhi laporan keuangan. 
Menurut Rahman dan Siregar (2012) dalam penugasan umum, auditor ditugasi untuk memberikan opini atas laporan keuangan suatu usaha. Opini audit dibedakan menjadi modified opinion dan unmodified opinion (Tuanakotta, 2013). Namun, seiring dengan meningkatnya kebutuhan pemakai laporan keuangan terhadap opini auditor atas laporan audit dalam membuat keputusan yang tepat untuk mengambil keputusan berinvestasi, maka auditor juga perlu melakukan audit mengenai kelangsungan hidup (going concern) suatu entitas, sehingga auditor lebih melakukan pertimbangan dalam memberikan opini audit going concern. Pemberian opini modifikasi (going concern) oleh auditor merupakan dampak keraguan perusahaan untuk dapat melakukan kelangsungan usahanya. Opini audit going concern merupakan opini yang diberikan auditor, apabila terdapat keraguan mengenai kelangsungan hidup suatu entitas. Opini ini merupakan bad news bagi pemakai laporan keuangan (Astuti \& Darsono, 2012).

Kondisi keuangan merupakan gambaran kondisi perusahaan secara nyata, bagaimana kinerja perusahaan selama ini. Kondisi keuangan juga merupakan suatu tampilan secara utuh atas keuangan perusahaan. Menurut McKeown (1991) dalam Dewayanto (2011), semakin memburuk atau terganggunya kondisi keuangan suatu perusahaan, maka semakin besar kemungkinan perusahaan menerima opini audit going concern. Kondisi keuangan dapat diukur dengan menggunakan beberapa model prediksi kebangkrutan, antara lain model Revised Altman's Z-Score, Springate S-Score, Zmijewski X-Score, dan Grover G-Score.

Audit tenure didefinisikan sebagai lama hubungan atau keterikatan antara auditor dengan kliennya yang diukur dengan jumlah tahun (Arsianto \& Rahardjo, 2013). Perikatan audit yang lama akan menjadikan auditor kehilangan independensinya, sehingga kemungkinan untuk memberikan opini audit going concern akan sulit (Ulya, 2012). Ukuran KAP (Kantor Akuntan Publik) juga mempengaruhi dalam pemberian opini audit going concern. Para pengguna laporan keuangan lebih mempercayai laporan keuangan yang diaudit oleh KAP yang berafiliasi dengan Big Four. KAP Big Four cenderung akan menerbitkan opini audit going concern, jika klien mengalami masalah berkaitan going concern perusahaan (Junaidi \& Hartono, 2010). Berdasarkan uraian di atas, maka penelitian ini bertujuan untuk menguji kembali pengaruh kondisi keuangan, audit tenure, dan ukuran KAP terhadap opini audit going concern yang menggunakan perusahaan manufaktur dari tahun 2012-2016.

\section{KAJIAN TEORITIS}

\section{Laporan Keuangan}

Laporan keuangan adalah suatu penyajian terstruktur dari posisi keuangan dan kinerja keuangan suatu entitas (PSAK, 2017). Menurut Kasmir (2017), laporan keuangan oleh perusahaan tidak dibuat secara serampangan, tetapi harus dibuat dan disusun sesuai dengan aturan dan standar yang berlaku. Hal ini perlu dilakukan agar laporan keuangan mudah dibaca dan dimengerti dan bertujuan apakah perusahaan dalam kondisi yang baik-baik saja atau terancam kelangsungan hidupnya. Laporan keuangan biasanya disusun atas dasar asumsi kelangsungan usaha entitas dan akan melanjutkan usahanya di masa depan (PSAK, 2017). 


\section{Opini Audit}

Opini audit (audit opinion) adalah pendapat auditor tentang laporan keuangan yang telah diauditnya (Islahuzzaman, 2012). Menurut Tuanakotta (2013), opini audit dibedakan menjadi modified opinion dan unmodified opinion.

\section{a. Modified opinion}

Suatu qualified opinion (pendapat wajar dengan pengecualian), adverse opinion (pendapat tidak wajar), atau disclaimer of opinion (tidak memberi pendapat).

\section{b. Unmodified opinion}

Opini yang diberikan auditor ketika ia menyimpulkan bahwa laporan keuangan telah disajikan, dalam segala hal yang material, sesuai kerangka pelaporan keuangan yang diterapkan (the applicable financial reporting framework).

\subsection{Opini Audit Going Concern}

Going concern merupakan keberlangsungan hidup suatu perusahaan. Menurut Ginting dan Tarihoran (2017), faktor-faktor yang dapat menimbulkan keraguan besar mengenai kelangsungan hidup perusahaan adalah:

a. Kerugian operasi atau defisit modal yang terus berulang dan dalam jumlah yang signifikan.

b. Ketidakmampuan perusahaan dalam memenuhi hampir seluruh kewajibannya.

c. Kehilangan pelanggan terbesar ("pelanggan mahkota").

d. Bencana yang tidak dijamin oleh asuransi, seperti banjir dan gempa bumi yang bersifat destruktif dan signifikan merugikan perusahaan.

e. Masalah ketenagakerjaan yang sangat serius.

f. Tuntutan pengadilan yang dapat "membahayakan" status serta kemampuan perusahaan untuk beroperasi.

Opini audit going concern merupakan opini audit modifikasi pertimbangan auditor dalam menilai ketidakmampuan atas kelangsungan hidup suatu entitas dalam menjalankan kegiatan usahanya (Wibisono, 2013).

\section{Kondisi Keuangan}

Kondisi keuangan perusahaan adalah suatu tampilan secara utuh atas keuangan perusahaan selama periode atau kurun waktu tertentu (Dewayanto, 2011). Kondisi keuangan ini menunjukkan bagaimana keadaan perusahaan sesungguhnya, apakah dalam kondisi yang baik, sehingga dapat mempertahankan kelangsungan hidupnya atau perusahaan dalam kondisi yang tidak baik, sehingga terancam kelangsungan perusahaan itu sendiri. Suatu perusahaan yang mengalami kerugian atau dalam posisi yang sulit untuk melunasi utangnya akan mempunyai kecenderungan untuk menunda penghapusan piutangnya yang sudah sulit untuk ditagih atau sediaan barang dagangannya yang sudah tidak laku dijual, atau lupa mencatat utangnya. Hal ini tidak mungkin terjadi dalam perusahaan yang keadaan kondisi keuangannya baik (Mulyadi, 2014).

\section{Audit Tenure}

Menurut Paino, et al (2010), audit tenure adalah lamanya waktu auditor tersebut secara berturut-turut telah melakukan pekerjaan audit terhadap suatu perusahaan. 
Standar profesional mensyaratkan Kantor Akuntan Publik (KAP) untuk menetapkan kebijakan dan prosedur untuk menentukan apakah akan menerima klien baru dan mempertahankan klien yang telah ada. Tujuan kebijakan ini adalah untuk meminimalkan kemungkinan auditor akan dihubungkan dengan klien yang tidak memiliki integritas, meningkatkan risiko bahwa terdapat salah saji yang material dan tidak terdeteksi oleh auditor (Messier, et al, 2008).

\section{Ukuran KAP}

Menurut Tuanakotta (2015) akuntan publik adalah seseorang yang telah memperoleh izin untuk memberikan jasa-jasa sebagaimana diatur dalam undangundang. Kantor Akuntan Publik (KAP) adalah badan usaha yang didirikan berdasarkan ketentuan peraturan perundang-undangan dan mendapatkan izin usaha berdasarkan Undang-Undang Akuntan Publik (Jusup, 2014). Ukuran KAP ini sama seperti reputasi KAP. KAP yang termasuk dalam The Big Four dianggap memiliki kemampuan yang lebih baik dalam melakukan audit daripada KAP yang tidak termasuk dalam The Big Four. Ketika Kantor Akuntan Publik mengklaim dirinya sebagai KAP bereputasi baik seperti The Big Four, maka mereka berusaha keras untuk menjaga nama baik dan menghindari tindakan-tindakan yang mengganggu nama baik KAP tersebut.

\section{Pengembangan Hipotesis}

\subsection{Kondisi Keuangan}

Kondisi keuangan dianggap mencerminkan bagaimana kinerja perusahaan tersebut. Untuk memahami bagaimana kondisi keuangan perusahaan, sesungguhnya dapat digunakan dengan model prediksi kebangkrutan. Model prediksi kebangkrutan yang bisa digunakan antara lain model Revised Altman, model Springate, model Zmijewski, dan model Grover. Menurut McKeown (1991) dalam Dewayanto (2011), semakin memburuk atau terganggunya kondisi keuangan suatu perusahaan, maka semakin besar kemungkinan perusahaan menerima opini audit going concern. Sebaliknya, perusahaan yang tidak pernah mengalami kesulitan keuangan, auditor tidak pernah memberikan opini audit going concern.

Berdasarkan hasil penelitian terdahulu yang dilakukan oleh Putrady dan Haryanto (2014) menunjukkan bahwa adanya tekanan keuangan yang besar yang dialami perusahaan akan menjadikan perusahaan berada pada kondisi yang tidak mampu membiayai perusahaan. Hal tersebut akan semakin memungkinkan auditor memberikan opini bahwa perusahaan dalam tekanan dan mempertanyakaan kemampuan kelangsungan hidup perusahaan. Penelitian yang dilakukan oleh Ibrahim dan Raharja (2014) membuktikan bahwa semakin baik kondisi keuangan perusahaan, maka semakin kecil kemungkinan perusahaan menerima opini going concern. Penelitian dengan hasil yang sama juga dilakukan oleh Wibisono (2013).

Ardiani dkk. (2012) menyatakan hasil yang berbeda yaitu kondisi keuangan tidak berpengaruh terhadap penerimaan opini audit going concern disebabkan auditor tidak hanya mempertimbangkan dari rasio keuangan perusahaan saja, tetapi auditor juga mempertimbangkan kondisi perekonomian pada saat itu. Hasil penelitian tersebut juga didukung oleh Astuti dan Darsono (2012). Berdasarkan uraian di atas maka dapat dirumuskan hipotesis sebagai berikut: 
$\mathrm{H}_{1}$ : Kondisi keuangan berpengaruh negatif terhadap opini audit going concern.

\subsection{Pengaruh Audit Tenure terhadap Opini Audit Going Concern}

Audit tenure adalah lamanya waktu auditor tersebut secara berturut-turut telah melakukan pekerjaan audit terhadap suatu perusahaan (Paino, et al, 2010). Menurut Januarti (2009), semakin lama hubungan klien dengan auditor dikhawatirkan akan mempengaruhi tingkat independensi auditor dalam memberikan pendapatnya, sehingga kemungkinan untuk memberikan opini going concern juga semakin kecil. Artinya, apabila seorang auditor melakukan audit laporan keuangan di suatu perusahaan secara berturut-turut, maka dapat mengurangi keindependensiannya. Hal tersebut dapat mempengaruhi hasil opini audit yang dikeluarkan oleh auditor.

Penelitian yang dilakukan oleh Putrady dan Haryanto (2014) tidak berpengaruh terhadap opini audit going concern, karena berkaitan dengan independensi dan profesionalitas KAP yang baik, sehingga meskipun sudah memiliki hubungan perikatan yang lama, tetapi KAP masih memiliki kemungkinan yang besar dalam memberikan opini audit going concern. Ardiani dkk. (2012) juga menyatakan hal yang sama bahwa audit tenure tidak berpengaruh terhadap penerimaan opini audit going concern. Menurut Yudhanto dan Mutmainah (2012) dalam penelitiannya menyatakan bahwa audit tenure berpengaruh positif terhadap opini audit going concern. Ketika auditor memiliki jangka waktu hubungan semakin lama dengan klien, hal itu akan memberikan dorongan pemahaman lebih luas atas kondisi klien dan oleh karenanya mereka akan cenderung mampu mendeteksi masalah going concern.

Selanjutnya, penelitian yang dilakukan oleh Arsianto dan Rahardjo (2013) menunjukkan hasil berpengaruh negatif terhadap penerimaan opini audit going concern. Artinya, perusahaan yang memiliki masa perikatan dengan KAP yang semakin lama akan memiliki probabilitas yang lebih kecil untuk menerima opini audit going concern, yakni semakin lama masa perikatan perusahaan dengan KAP akan cenderung mengurangi tingkat independensi KAP dalam memberikan opini atas laporan keuangan yang diauditnya. Berdasarkan uraian di atas maka dapat dirumuskan hipotesis sebagai berikut:

$\mathrm{H}_{2}$ : Audit tenure berpengaruh terhadap opini audit going concern.

\subsection{Pengaruh Ukuran KAP terhadap Opini Audit Going Concern}

Menurut DeAngelo (1981) dalam Setyarno dkk. (2006) menyatakan bahwa auditor skala besar memiliki insentif yang lebih untuk menghindari kritikan kerusakan reputasi dibandingkan pada auditor skala kecil. Auditor skala besar juga lebih cenderung untuk mengungkapkan masalah-masalah yang ada karena mereka lebih kuat menghadapi risiko proses pengadilan. Argumen tersebut berarti bahwa auditor skala besar memiliki kemungkinan atau dorongan yang lebih untuk melaporkan masalah going concern kliennya, apabila terbukti klien mengalami masalah untuk melangsungkan usahanya dibandingkan auditor skala kecil.

KAP yang termasuk dalam big four dianggap dapat mengeluarkan pendapat apa adanya, apakah perusahaan akan mendapat opini audit going concern atau opini audit non-going concern. Ukuran KAP berkaitan dengan reputasi auditor, yaitiu apabila auditor mengeluarkan pendapat yang tidak sesuai dapat mempengaruhi kredibilitas dan reputasinya sebagai seorang auditor. Penelitian yang dilakukan oleh Astuti dan Darsono 
(2012) menyatakan hasil yang berpengaruh negatif terhadap opini audit going concern. Hasil tersebut tidak didukung oleh penelitian yang dilakukan oleh Ardiani dkk. (2012). Menurut Santosa dan Wedari (2007) dalam Ardiani dkk. (2012), KAP yang memiliki kualitas lebih tinggi cenderung akan mengeluarkan opini audit going concern.

Yudhanto dan Mutmainah (2012) menyatakan bahwa reputasi auditor tidak berpengaruh terhadap opini audit going concern. Kondisi ini disebabkan karena perusahaan yang menggunakan KAP The Big Four tidak menjadi jaminan untuk mendapatkan unqualified opinion atau pun opini going concern. Sebaliknya, perusahaan yang tidak menggunakan The Big Four mendapat opini going concern. Hasil penelitian ini juga didukung oleh hasil penelitian yang dilakukan oleh Arsianto dan Rahardjo (2013). Berdasarkan uraian di atas maka dapat dirumuskan hipotesis sebagai berikut:

$\mathrm{H}_{3}$ : Ukuran KAP berpengaruh terhadap opini audit going concern.

\section{METODE PENELITIAN}

\section{Populasi dan Sampel}

Populasi dalam penelitian ini adalah seluruh perusahaan manufaktur yang terdaftar di Bursa Efek Indonesia tahun 2012 sampai tahun 2016.

\section{Tabel 1. Sampel Penelitian}

\begin{tabular}{cr}
\hline \multicolumn{1}{c}{ Keterangan } & Jumlah \\
\hline Total perusahaan manufaktur yang terdaftar di BEI tahun $2012-2016$ & 144 \\
\hline Peneliti tidak bisa mendapatkan laporan tahunan tahun $2012-2016$ & $(39)$ \\
\hline Laporan keuangan yang tidak memiliki data lengkap atas variabel yang dibutuhkan & $(0)$ \\
\hline Laporan keuangan yang tidak disajikan dalam rupiah (Rp) & $(25)$ \\
\hline Total & $\mathbf{8 0}$ \\
\hline Total Data Observasi (80 perusahaan x 5 tahun) & $\mathbf{4 0 0}$ \\
\hline
\end{tabular}

\section{Data dan Sumber}

Data yang digunakan dalam penelitian ini adalah data sekunder. Data sekunder dalam penelitian ini adalah laporan tahunan perusahaan yang diperoleh dari www.idx.co.id.

\section{Definisi Operasional dan Pengukuran}

Variabel yang digunakan dalam penelitian ini adalah variabel dependen, yaitu opini audit going concern dan variabel independen yaitu kondisi keuangan, audit tenure, dan ukuran KAP.

\section{Variabel Dependen}

Variabel dependen yang digunakan dalam penelitian ini adalah opini audit going concern. Opini audit going concern merupakan opini yang menunjukkan bahwa perusahaan dianggap tidak dapat mempertahankan kelangsungan hidupnya. Perusahaan yang mendapat opini audit going concern akan diberi kode 1, sedangkan perusahaan yang mendapat opini audit non-going concern akan diberi kode 0 . 


\section{Variabel Independen}

Variabel independen yang digunakan pada penelitian ini adalah kondisi keuangan, audit tenure, dan ukuran KAP.

\section{a. Kondisi Keuangan}

Kondisi keuangan perusahaan adalah suatu tampilan secara utuh atas keuangan perusahaan selama periode atau kurun waktu tertentu (Dewayanto, 2011).

\section{Model Revised Altman Z'-Score}

$$
Z=0,717 X_{1}+0,847 X_{2}+3,107 X_{3}+0,420 X_{4}+0,988 X_{5}
$$

Keterangan:

$$
\begin{array}{ll}
X_{1} & =\text { Working Capital / Total Asset } \\
X_{2} & =\text { Retained Earnings / Total Asset } \\
X_{3} & =\text { Earning Before Interest and Taxes / Total Asset } \\
X_{4} & =\text { Book Value of Equity / Book Value of Debt } \\
X_{5} & =\text { Sales/Total Assset }
\end{array}
$$

\section{Model Springate S-Score}

$$
\mathrm{S}=1,03 \mathrm{~A}+3,07 \mathrm{~B}+0,66 \mathrm{C}+0,4 \mathrm{D}
$$

Keterangan:
A $\quad=$ Working Capital / Total Asset
$\mathrm{B} \quad=$ Net Profit Before Interest and Taxes / Total Asset
$\mathrm{C} \quad=$ Net Profit Before Taxes $/$ Current Liabilities
$\mathrm{D} \quad=$ Sales $/$ Total Asset

\section{Model Zmijewski X-Score}

$$
X=-4,3-4,5 X_{1}+5,7 X_{2}-0,004 X_{3}
$$

Keterangan:

$$
\begin{array}{ll}
X_{1} & =\text { ROA (Return on Asset) } \\
X_{2} & =\text { Leverage (Debt Ratio) } \\
X_{3} & =\text { Likuiditas (Current Ratio) }
\end{array}
$$

\section{Model Grover G-Score}

$$
\mathrm{G}=1,650 \mathrm{X}_{1}+3,404 \mathrm{X}_{2}-0,016 \mathrm{ROA}+0,057
$$

Keterangan:

$X_{1} \quad=$ Working Capital / Total Assets

$X_{2} \quad=$ Earnings Before Interest and Taxes / Total Assets

ROA = Net Income / Total Assets

\section{b. Audit Tenure}

Audit tenure adalah lama hubungan atau keterikatan antara auditor dengan kliennya yang diukur dengan jumlah tahun (Arsianto \& Rahardjo, 2013). Audit tenure diukur dengan menggunakan skala interval sesuai dengan lamanya perikatan antara KAP dengan auditee yang sama. 


\section{c. Ukuran KAP}

Kantor Akuntan Publik (KAP) adalah badan usaha yang didirikan berdasarkan ketentuan perturan perundang-undangan dan mendapatkan izin usaha berdasarkan Undang-Undang Akuntan Publik (Jusup, 2014). Ukuran KAP diukur menggunakan variabel dummy, yaitu KAP yang tergabung dalam The Big Four akan diberikan kode angka 1, sedangkan KAP yang tidak tergabung dalam The Big Four akan diberikan kode angka 0.

\section{HASIL DAN PEMBAHASAN}

Pengujian hipotesis dalam penelitian ini menggunakan analisis regresi logistik. Hasil analisis regresi logistik disajikan dalam Tabel 2 berikut ini:

Tabel 2. Hasil Pengujian Hipotesis

\begin{tabular}{lrrrr}
\hline \multicolumn{1}{r}{ Variabel } & \multicolumn{1}{c}{$\boldsymbol{\beta}$} & \multicolumn{1}{c}{ SE } & \multicolumn{1}{c}{ Wald } & \multicolumn{1}{c}{ Sig } \\
\hline Altman Revisi & -.094 & .130 & .517 & .472 \\
Springate & .149 & .181 & .677 & .411 \\
Zmijewski & .191 & .091 & 4.388 & .037 \\
Grover & .016 & .248 & .004 & .947 \\
Audit Tenure & -.259 & .053 & 23.596 & .000 \\
Ukuran KAP & -.093 & .246 & .141 & .707 \\
Kontanta & .877 & .272 & 10.387 & .001 \\
\hline
\end{tabular}

Hosmer and Lemeshow Test:

- Chi-Square: 5,490

- Sig: 0,704

Negelkerke R Square: .147

Hasil Hosmer and Lemeshow Test yang tampak pada Tabel 2 menunjukkan hasil nilai Chi-Square sebesar 5,490 dengan probabilitas (p) sebesar 0,704. Nilai probabilitas (p) $>0,05$ maka dapat disimpulkan bahwa model regresi layak untuk digunakan dalam analisis selanjutnya. Tabel 2 juga menunjukkan nilai Negelkerke $R$ Square sebesar 0,147 yang berarti variabilitas variabel dependen yang dapat dijelaskan oleh variabel independen adalah sebesar 14,7 persen, sisanya 85,3 persen dijelaskan oleh variabelvariabel lain di luar model penelitian.

\section{Pengujian Hipotesis}

Berdasarkan hasil analisis regresi pada Tabel 2, variabel kondisi keuangan yang diproksikan dengan model Revised Altman diperoleh koefisien regresi sebesar -0,094 dan nilai signifikansi sebesar 0,472 . Untuk kondisi keuangan yang diproksikan dengan model Springate diperoleh nilai koefisien regresi sebesar 0,149 dan nilai signifikansi sebesar 0,411. Untuk kondisi keuangan yang diproksikan dengan model Zmijewski diperoleh nilai koefisien regresi sebesar 0,191 dan nilai signifikansi sebesar 0,037, dan kondisi keuangan yang diproksikan dengan model Grover diperoleh nilai koefisien regresi sebesar 0,016 dan nilai signifikansi sebesar 0,947. Maka dapat disimpulkan bahwa kondisi keuangan berpengaruh terhadap opini audit going concern yang mana 
model prediksi kebangkrutan yang paling baik digunakan adalah model Zmijewski. Nilai koefisien regresi pada model Zmijewski bertanda positif, sehingga menunjukkan bahwa kondisi keuangan berpengaruh positif terhadap opini audit going concern.

Berdasarkan hasil analisis regresi pada variabel audit tenure diperoleh nilai koefisien regresi sebesar $-0,259$ dan nilai signifikansi sebesar 0,000, sehingga dapat disimpulkan bahwa audit tenure berpengaruh terhadap opini audit going concern. Koefisien regresi menunjukkan tanda negatif, sehingga memberikan hasil bahwa audit tenure berpengaruh negatif terhadap opini audit going concern.

\section{a. Pengaruh Kondisi Keuangan terhadap Opini Audit Going Concern}

Variabel kondisi keuangan diproksikan dengan empat model prediksi kebangkrutan dengan tujuan untuk mengetahui mana model prediksi kebangkrutan yang paling baik digunakan di Indonesia. Setelah dilakukan pengujian regresi dapat disimpulkan bahwa model yang paling baik digunakan di Indonesia adalah model Zmijewski. Hal tersebut dikarenakan model prediksi kebangkrutan yang diproksikan dengan model Zmijewski menghasilkan nilai koefisien regresi sebesar 0,191 dan nilai signifikansi sebesar 0,037 , sedangkan model prediksi kebangkrutan yang lain menunjukkan hasil yang tidak berpengaruh. Selanjutnya, dapat disimpulkan bahwa kondisi keuangan yang diproksikan dengan model Zmijewski berpengaruh positif terhadap opini audit going concern. Hal ini menunjukkan bahwa dalam memberikan opini audit going concern, auditor melihat bagaimana kondisi keuangan perusahaan tersebut. Apabila prediksi kebangkrutannya semakin tinggi, maka kemungkinan perusahaan mendapat opini audit going concern akan semakin tinggi pula. Hal tersebut sesuai dengan model Zmijewski, yaitu semakin tinggi nilai yang diperoleh perusahaan, maka penerimaan opini audit going concern akan semakin tinggi. Pengujian kondisi keuangan ini sesuai dengan yang dilakukan oleh Setyarno dkk. (2006). Perbedaan dari penelitian yang dilakukan oleh Setyarno dkk. (2006) terletak pada model prediksi kebangkrutan yang digunakan.

Hasil penelitian ini tidak mendukung penelitian yang dilakukan oleh Putrady dan Haryanto (2014), Wibisono (2012), serta Ibrahim dan Raharja (2014) yang menyatakan bahwa kondisi keuangan berpengaruh negatif terhadap opini audit going concern. Semakin baik kondisi keuangan perusahaan, maka semakin kecil kemungkinan perusahaan menerima opini going concern (Ibrahim dan Raharja, 2014). Hasil berbeda juga ditunjukkan oleh penelitian yang dilakukan oleh Astuti dan Darsono (2012) dan Ardiani dkk. (2012) yang menyatakan bahwa kondisi keuangan tidak berpengaruh terhadap opini audit going concern. Hal tersebut dapat terjadi karena penilaian auditor dalam memberikan opini audit going concern tidak pada keseluruhan kondisi keuangan perusahan. tetapi kondisi keuangan tertentu seperti status default hutang (Astuti dan Darsono, 2012).

\section{b. Pengaruh Audit Tenure terhadap Opini Audit Going Concern}

Hasil pengujian regresi menunjukkan bahwa variabel audit tenure berpengaruh negatif terhadap opini audit going concern. Hal ini ditunjukkan dari nilai koefisien regresi sebesar $-0,259$ dan nilai signifikansi sebesar 0,000, sehingga dapat disimpulkan bahwa audit tenure berpengaruh terhadap opini audit going concern. Hal ini sesuai dengan hipotesis penelitian yang menyatakan bahwa audit tenure berpengaruh negatif terhadap opini audit going concern. Semakin lama hubungan klien dengan auditor dikhawatirkan akan mempengaruhi tingkat independensi 
auditor dalam memberikan pendapatnya, sehingga kemungkinan untuk memberikan opini going concern juga semakin kecil (Januarti, 2009).

Hasil penelitian ini sesuai dengan penelitian yang dilakukan oleh Arsianto dan Rahardjo (2013). Penelitian yang dilakukan oleh Arsianto dan Rahardjo (2013) membuktikan perusahaan yang memiliki masa perikatan dengan KAP yang semakin lama akan memiliki probabilitas yang lebih kecil untuk menerima opini audit going concern, yaitu semakin lama masa perikatan perusahaan dengan KAP akan cenderung mengurangi tingkat independensi KAP dalam memberikan opini atas laporan keuangan yang diauditnya.

Namun, hasil penelitian ini tidak sesuai dengan penelitian yang dilakukan Yudhanto dan Mutmainah (2012) bahwa audit tenure berpengaruh positif terhadap opini audit going concern. Hal tersebut dikarenakan ketika auditor memiliki jangka waktu perikatan semakin lama dengan klien, ini akan memberikan dorongan pemahaman lebih luas atas kondisi klien dan oleh karenanya, mereka akan cenderung mampu mendeteksi masalah going concern. Hasil penelitian ini juga tidak sesuai dengan Putrady dan Haryanto (2014) dan Ardiani dkk. (2012) yang menunjukkan hasil audit tenure tidak berpengaruh terhadap opini audit going concern. Menurut Putrady dan Haryanto (2014), hal tersebut dikarenakan berkaitan dengan independensi dan profesionalitas KAP yang baik, sehingga meskipun sudah memiliki hubungan perikatan yang lama, tetapi KAP masih memiliki kemungkinan yang besar dalam memberikan opini audit going concern.

\section{c. Pengaruh Ukuran KAP terhadap Opini Audit Going Concern}

Pengujian yang dilakukan menggunakan variabel ukuran KAP diperoleh hasil bahwa ukuran KAP tidak berpengaruh terhadap opini audit going concern. Pengujian regresi logistik menunjukkan nilai signifikansi sebesar 0,707 . Penelitian ini tidak mendukung hipotesis bahwa ukuran KAP berpengaruh terhadap opini audit going concern. Hasil penelitian ini mendukung penelitian yang dilakukan oleh Yudhanto dan Mutmainah (2012) dan Arsianto dan Rahardjo (2013) bahwa ukuran KAP tidak berpengaruh terhadap opini audit going concern. Menurut Yudhanto dan Mutmainah (2012), perusahaan yang menggunakan KAP The Big Four tidak menjadi jaminan untuk mendapatkan unqualified opinion atau pun opini going concern. Sebaliknya, perusahaan yang tidak menggunakan The Big Four mendapat opini going concern. Sebagai contoh, perusahaan Argha Karya Prima Industry Tbk. menggunakan KAP Purwantono, Suherman, Surja yang merupakan afiliasi Ernst \& Young Global (big four) mendapatkan opini audit going concern, sedangkan perusahaan Duta Pertiwi Nusantara yang menggunakan KAP Paul Hadiwinata, Hidajat, Arsono, Ade Fatma, \& Rekan yang merupakan afiliasi PKF (bukan big four) mendapatkan opini audit non-going concern.

Penelitian ini tidak sejalan dengan penelitian yang dilakukan oleh Astuti dan Darsono (2012), yaitu hasil penelitian menunjukkan ukuran KAP berpengaruh negatif terhadap opini audit going concern. Penelitian ini juga tidak sejalan dengan penelitian yang dilakukan oleh Ardiani dkk. (2012) yang menyatakan bahwa ukuran KAP berpengaruh positif terhadap opini audit going concern. Menurut Santosa dan Wedari (2007) dalam Ardiani dkk. (2012), KAP yang memiliki kualitas lebih tinggi cenderung akan mengeluarkan opini audit going concern. 


\section{SIMPULAN}

Berdasarkan hasil analisis yang telah dilakukan, maka dapat disimpulkan bahwa kondisi keuangan berpengaruh positif terhadap opini audit going concern. Dalam penelitian ini, kondisi keuangan diproksikan menggunakan empat model prediksi kebangkrutan yang mana hasil penelitian menunjukkan bahwa model prediksi Zmijewski menunjukkan hasil yang paling baik dibanding Revised Altman, Springate, dan Grover. Di sisi lain, audit tenure berpengaruh negatif terhadap opini audit going concern, tetapi ukuran KAP tidak berpengaruh terhadap opini audit going concern.

\section{DAFTAR REFERENSI}

Agoes, S. (2017). Auditing (Petunjuk Praktis Pemeriksaan Akuntan oleh Akuntan Publik). Jakarta: Salemba Empat.

Ardiani, N., Nur E., \& Azlina, N. (2012). Pengaruh Audit Tenure, Disclosure, Ukuran KAP, Debt Default, Opinion Shopping, dan Kondisi Keuangan Terhadap Penerimaan Opini Audit Going Concern Pada Perusahaan Real Estate dan Property di Bursa Efek Indonesia. Jurnal Ekonomi Vol. 20, No. 4, hal 1-21.

Arsianto, M. R., \& Rahardjo, S. N. (2013). Faktor-Faktor yang Mempengaruhi Penerimaan Opini Audit Going Concern. Diponegoro Journal of Accounting Vol. 2, No. 3, hal $1-8$.

Astuti, I. R, \& Darsono. (2012). Pengaruh Faktor Keuangan dan Non Keuangan Terhadap Penerimaan Opini Audit Going Concern. Diponegoro Journal of Accounting Vol 1, No. 2, hal 1-10.

Carey, P. \& Simnet, R. (2006). Audit Partner Tenure and Quality. The Accounting Review 81, p. $653-678$.

Dewayanto, T. (2011). Analisis Faktor-Faktor Yang Mempengaruhi Penerimaan Opini Audit Going Concern Pada Perusahaan Manufaktur yang Terdaftar di Bursa Efek Indonesia. Jurnal Fokus Ekonomi Vol. 6 No. 1, hal 81-104.

Fernando, R, \& Hadiprajitno, P. B. (2015). Analisis Faktor Yang Berpengaruh Terhadap Penerimaan Opini Audit Going Concern. Diponegoro Journal of Accounting Vol. 4, No. 3, hal 1-10.

Ghozali, I. (2009). Aplikasi Analisis Multivariate dengan Program SPSS. Semarang: Universitas Diponegoro.

Ginting, S., \& Tarihoran, A. (2017). Faktor-Faktor yang Mempengaruhi Pernyataan Going Concern. Jurnal Wira Ekonomi Mikrosil Vol. 7, No.1, hal 9-20.

Hartono, J. (2013). Metodologi Penelitian Bisnis. Yogyakarta: BPFE.

Ibrahim, S. P, \& Raharja (2014). Pengaruh Audit Lag, Rasio Leverage, Rasio Arus Kas, Opini Audit Tahun Sebelumnya, dan Financial Distress Terhadap Penerimaan Opini Going Concern (Studi pada Perusahaan Manufaktur yang Terdaftar di BEI Tahun 2009-2012). Diponegoro Journal of Accounting Vol. 3 No. 3, hal 1-11.

Islahuzzaman (2012). Istilah Akuntansi \& Auditing. Edisi Kesatu. Jakarta: Bumi Aksara.

Januarti, I. \& Fitrianasari, E. (2008). Analisis Rasio Keuangan dan Rasio Non Keuangan yang Mempengaruhi Auditor dalam Memberikan Opini Audit Going Concern pada Auditee (Studi Empiris pada Perusahaan Manufaktur yang Terdaftar di BEJ 20002005). Jurnal Maksi Vol. 8 No. 1, hal 43-58. 
Januarti, I. (2009). Analisis Pengaruh Faktor Perusahaan, Kualitas Auditor, Kepemilikan Perusahaan Terhadap Penerimaan Opini Going Concern. Simposium Nasional Akuntansi XII.

Junaidi \& Hartono, J. (2010). Faktor Non Keuangan Pada Opini Audit Going Concern. Simposium Nasional Akuntansi XII.

Jusup, H. (2014). Auditing (Pengauditan Berbasis ISA). Yogyakarta: STIE-YKPN.

Kasmir (2017). Analisis Laporan Keuangan. Jakarta: Rajawali Pers.

Messier et al. (2008). Auditing \& Assurance Services: A Systematic Approach 6th edition. McGraw-Hill Co.

Paino, H., Ismail, H., \& Smith, M. (2010). Dysfungsional Audit Behavior: An Explanatory Study in Malaysia. Journal Asian Review of Accounting Edith Coward University Reasearch Online.

Peraturan Menteri Keuangan No. 17/PMK.01/2008. Diakses https://www.onlinepajak.com/id/peraturan-menteri-keuangan-17pmk012008 pada tanggal 15 Desember 2017.

Prihantini, N.M.E.D. \& Sari, M.M.R. (2013). Prediksi Kebangkrutan dengan Model Grover, Altman Z-Score, Springate, dan Zmijewski pada Perusahaan Food and Beverge di Bursa Efek Indonesia. E-Jurnal Akuntansi Universitas Udayana, hal 417-435.

Putrady, C. P. \& Haryanto (2014). Analisis Faktor Keuangan dan Non Keuangan Yang Mempengaruhi Penerimaan Opini Audit Going Concern. Diponegoro Journal of Accounting Vol 3 No 2, hal 1-12.

Rahman, A. \& Siregar, B. (2012). Faktor-Faktor Yang Mempengaruhi Kecenderungan Penerimaan Opini Audit Going Concern Pada Perusahaan Manufaktur Yang Terdaftar di Bursa Efek Indonesia. Simposium Nasional Akuntansi XV Banjarmasin.

Ramadhani, A. S. \& Lukviarman, N. (2009). Perbandingan Analisis Prediksi Kebangkrutan Menggunakan Model Altman Pertama, Altman Revisi, dan Altman Modifikasi dengan Ukuran dan Umur Perusahaan Sebagai Variabel Penjelas (Studi pada Perusahaan Manufaktur yang Terdaftar di Bursa Efek Indonesia). Jurnal Siasat Bisnis Vol. 13 No. 1, hal 15-28.

Setyarno, E. B., Januarti, I., \& Faisal (2006). Pengaruh Kualitas Audit, Kondisi Keuangan Perusahaan, Opini Audit Sebelumnya, Pertumbuhan Perusahaan Terhadap Opini Audit Going Concern. Simposium Nasional Akuntansi IX, hal 1-25.

Tuanakotta, T. M. (2014). Audit Berbasis ISA (International Standards on Auditing). Jakarta: Salemba Empat.

Tuanakotta, T. M. (2015). Audit Kontemporer. Jakarta: Salemba Empat.

Ulya, A. (2012). Opini Audit Going Concern: Analisis Berdasarkan Faktor Keuangan dan Non Keuangan. Accounting Analisis Journal Vol 1, No. 1.

Venuti, E. K. (2007). The Going Concern Assumption Revisited: Assessing a Company's Future Viability. The CPA Journal Online.

Wibisono, E. A. (2013). Prediksi Kebangkrutan, Leverage, Audit Sebelumnya, Ukuran Perusahaan Terhadap Opini Going Concern Perusahaan Manufaktur BEI. Jurnal Riset Ekonomi, Manajemen, Bisnis, dan Akuntansi Universitas Sam Ratulangi Manado Vol 1 No. 4, hal 362-373.

Yudhanto, A. A. \& Mutmainah, S. (2012). Faktor-Faktor Non Keuangan Yang Mempengaruhi Dikeluarkannya Opini Going Concern. Diponegoro Journal of Accounting Vol. 1, hal 1-14. 